\title{
A review of the soft side in project management: concept, trends and challenges
}

Luiz Fernando Cardoso dos Santos Durão ${ }^{1}$ - Univ. de São Paulo - Escola Politécnica - Dep. de Eng. de Produção Marcelo Vinicius Di Favari Grotti² - Univ. de São Paulo - Escola Politécnica - Dep. de Eng. de Produção Paulo Rafael Minetto Maceta ${ }^{3}$ - Univ. de São Paulo - Escola Politécnica - Dep. de Eng. de Produção Eduardo de Senzi Zancul4 - Univ. de São Paulo - Escola Politécnica - Dep. de Eng. de Produção Fernando Tobal Berssaneti ${ }^{5}$ - Univ. de São Paulo - Escola Politécnica - Dep. de Eng. de Produção Marly Monteiro Carvalho6 6 - Univ. de São Paulo - Escola Politécnica - Dep. de Eng. de Produção

ABSTRACT Our aim is to analyze the changes that have taken place in the academic literature of project management induced by the growing interest in the soft side within project management, identifying concepts, trends and challenges. Based on a bibliometric approach, a systematic literature review focusing on content analysis was made in articles published from 1994 to 2015 in the ISI Web of Science and Scopus databases. The literature was found to maintain the separation between the hard and the soft side, being the soft side, for most researchers, an enabler of project performance and success. Each kind of examined skills provides different aspects of project quality and management, being the hard side clearer and more objective and the soft side more ambiguous and subjective. In the whole article, the base used 13 soft skills. The most cited among them was 'Communication', cited fifteen times, followed by 'Leadership' and 'Teamwork' cited nine times each. Despite the stronger impact of the soft skills in the project performance, the literature says that the project members, within the project team, must combine soft and hard skills towards the best performance of the projects.

Keywords: Soft Side. Soft Skills. Project Management. 


\section{INTRODUCTION}

In recent years, project management scholars have highlighted the need to go beyond the prescriptive characteristics of project management (AHLEMANN et al., 2013), devoting more effort to soft skills (SÖDERLUND; MAYLOR, 2012), since they seem to have a significant impact on project success (CARVALHO; RABECHINI JUNIOR, 2015).

The boundaries between the hard and the soft side in project management are fuzzy. For Karrbom Gustavsson and Hallin (2014) the dichotomization between hard and soft in project management research seems to be more related to the academic community than to practitioners, and these approaches are most often combined. This is partly explained by the fact that certifications body of knowledge, such as the Project Management Institute, commonly attribute more emphasis to the hard side aspects. Besides, the academic community has dedicated efforts to research soft aspects for personnel preparation and qualification, as described in section 3.

The soft side is still an open research issue due to the wide range of topics within its boundaries, such as ecodesign integration (BRONES; CARVALHO, 2014), communication (CARVALHO; RABECHINI JUNIOR, 2015; FLETCHER; GUNNING; COATES, 2014; JOSEPH; ERASMUS; MARNEWICK, 2014) and self-realization, and fulfillment (TAGHAVI; TAGHAVI; TAGHAVI, 2013). The soft side involves the different levels of analysis, i.e., organization, project, and individuals. It encompasses several issues such as interpersonal relationships and the notion of project ecology (GRABHER, 2004), power conflicts, trust, and learning (SÖDERLUND; MAYLOR, 2012), as well as the organizational context (SHARMA; GUPTA, 2012; SÖDERLUND; MAYLOR, 2012).

The project management soft side issue has already been the subject of some previous literature reviews (BRONES; CARVALHO, 2014; HERAZO; LIZARRALDE; PAQUIN, 2012; KARRBOM GUSTAVSSON; HALLIN, 2014). The importance of the soft side for projects success is highlighted by Herazo, Lizarralde and Paquin (2012). Karrbom Gustavsson and Hallin (2014) discuss the trap of dichotomization; and Brones and Carvalho (2014) focus on ecodesign. Moreover, the issue has also already been the object of surveys. The most prevalently identified method, applied by $43 \%$ of the literature surveyed, such as Carvalho and Rabechini Junior (2015), Joseph, Erasmus and Marnewick (2014), Yng Ling and $\mathrm{Ma}$ (2014), and Ahsan, Ho and Khan (2013), to name a few studies applied to different contexts. Encompassing $21 \%$ of the articles sampled, case studies were also found to be a significant research method applied, represented in the articles sample analysed by Plant and Willcocks (2007), Shurville and Williams (2005); Soares et al. (2013), and Walker and Shen (2002). 
Nevertheless, a precise definition of the soft side main characteristics has not reached a consensus, and the literature involves different epistemological fields. However, researches agree that soft skills are related with project managers' needs of improving project performance, as identified in the literature. It defines the interpersonal relationships between the project members.

This paper intends to go further into reviewing the literature regarding the soft side of project management by exploring its meaning at different levels of analysis. By a comprehensive search carried out in two databases with an extensive search string, as described in the following section, it intends to summarize and to consolidate the existing body of knowledge related to this theme, identifying which the essential characteristics of the soft side are and how they can affect project management performance and success.

This paper is structured into five sections. Section 1 presents the research, its context, and its objectives. Section 2 describes the methodological approach. Section 3 shows the results. Section 4 discusses the findings, and Section 5 presents the conclusions.

\section{SOFT SIDE CONCEPT}

The project management soft side is important for preparing future professionals. Fletcher, Gunning and Coates (2014) show a significant aspect of the soft skills related to training the staff, highlighting current deficiencies that could lead to a poor project performance. The consideration of soft aspects for personnel preparation and qualification has been identified as a research concern, as several works dealing with that were identified. Soares et al. (2013) and Post and Lee (2011) report university program cases in which not only technical competencies are developed, but also soft skills, such as project management, teamwork, communication ability and personal development, emphasizing their importance for students' future career and increasingly emphasizing soft aspects among the professinal community. The development of students' soft skills was also approached in Stevenson and Starkweather (2010) and Toor and Ofori (2008).

The academic concerns regarding the development of soft skills are entirely justifiable by Ahsan, Ho and Khan (2013) showing that job advertisements have required soft skills competencies. The study demonstrated the awareness that companies' human resources departments have of soft skills in the project management domain. Besides, Ahsan, Ho and Khan (2013) say that industry job advertisements emphasize "soft skills" and competencies differently from the literature, and Lent and Pinkowska (2012) say that the human factor-related skills demanded in advertisements vary in different cultures. 
The project management soft side has been part of professionals' preparation and selection. Soft skills are related with project managers' needs of improving project performance, as identified in the literature. For instance, in Fletcher, Gunning and Coates (2014), Yng Ling and Ma (2014), Zhang, Zuo and Zillante (2013) and, Zhang and Fan (2013) in the construction area, Joseph, Erasmus and Marnewick (2014), Lent and Pinkowska (2012), Parolia, Jiang and Klein, (2013), Petter and Randolph (2009), Plant and Willcocks (2007) and, Shurville and Williams (2005) in the Information and Communication Technologies Industry, and Soares et al. (2013), Taghavi, Taghavi and Taghavi, (2013) and, Wautelet and Kolp (2012) on education.

Most of the analyzed documents mentioned or dealt with the relations between the soft side and project success. First of all, in his work about the importance of training and development, Kilkelly (2011) states that interpersonal and persuasive skills are required for project managers and team members as a prerequisite for project success, similarly to Beukers (2011) as a result of his survey on project characteristics, challenges and training needs. Taking the project success as a dependent variable, in a survey, Carvalho and Rabechini Junior (2015) approached the importance of the soft skills in the project risk management, and their results show that the soft side has a significant positive impact not only on the hard side but also on the project success. This suggests that "the soft side plays a crucial role and that firms should consider soft skills because their effect on project success is highly significant and positive" (CARVALHO; RABECHINI JUNIOR, 2015). Surveying the factors influencing the project outcomes in the ICT field, Fletcher, Gunning and Coates (2014) concluded that they depend on the soft side more than on the hard side. Projects outcomes were also the subject of a survey in the construction field performed by Yng Ling and $\mathrm{Ma}$ (2014), detailing communication issues and focusing on their importance, which was corroborated by the eight measured items. A comprehensive and relevant literature review on the importance of the soft side for the success of projects were made by Herazo, Lizarralde and Paquin (2012) which not only reinforced its importance but also presented other authors and works that had previously concluded the same. Parker et al. (2013) listed the soft skills usually avoided by project management methodologies, while Alfaadel et al. (2014) showed that the project manager competency and leadership and the soft skills of the project team are two of the most important reasons for preventing project failures. The relations between emotional intelligence and project performance were approached in a survey conducted by Zhang and Fan (2013), mainly reporting its largely unexplored benefits in the construction field. 
One interesting branch of research designs a framework classifying the soft skills, and in some cases the hard ones, as independent variables, which affects the dependent variables, mainly considered as project success and performance. In these cases, there is a third variable nominated moderating variables, which should modulate the impact of the independent variables on the dependent ones. Carvalho and Rabechini Junior (2015) state that industry and project complexity are moderating variables. Herazo, Lizarralde and Paquin (2012) have another focus and classify the organizational dynamic as a moderating variable.

Although some research is based only on soft skills, there are some studies that compare soft skills with hard skills (ANDERSEN et al., 2006; BEUKERS, 2011; CARVALHO; RABECHINI JUNIOR, 2015; JOSEPH; ERASMUS; MARNEWICK, 2014; KARRBOM GUSTAVSSON; HALLIN, 2014; PANT; BAROUDI, 2008; SHURVILLE; WILLIAMS, 2005; YNG LING; MA, 2014). Most believe that soft skills more strongly influence project success or project performance than hard skills. On the other hand, a few articles, such as Wautelet and Kolp (2012) observed a greater influence on the project outcome from hard skills than from soft skills, saying that soft skills are complementary to hard skills.

Carvalho and Rabechini Junior (2015) advance in the analysis of soft and hard skills, applying structural equation modeling, by identifying that soft skills enable hard skills and impact project success. In other words, soft skills support hard skills making them more efficient, which lead to a better performance. This stresses the importance of soft skills in project management practice. In the same way, Taghavi, Taghavi and Taghavi (2013) states that managerial and intellectual competencies are complemented by soft skills making them have greater influence on a research project success.

Hard and soft sides can be defined as technical and behavioral sides, respectively (ANDERSEN et al., 2006). In more detail and comprehensively, the dichotomy between both sides is explored by Karrbom Gustavsson and Hallin (2014), who points to a relation on the hard side with positivist and realist thinking, as well as the search for objective knowledge; the authors relate the soft side to the interpretive and constructivist perspectives, and the intersubjective building of knowledge. Stating that "hard" and "soft" are used to distinguish between various dimensions and features of projects and programs, such as approaches, methodologies, systems, goals, outcomes, aspects, criteria, measures, costs, situations, issues, knowledge, ideas, logic, values and skills, their work goes further by classifying hard and soft projects, skills, issues, qualities and dimensions. 
The dichotomy between both sides was also found to be considered in the work by Li et al. (2010). Likewise, those authors classified the sides as centrifugal and centripetal Forces, being centrifugal competencies required at the start of a project to generate creativity, thus technical hard side, and centripetal, the competencies required to connect all of the essential elements and keep the project moving toward its goals, thus behavioral soft side.

Focused on the necessary soft skills in the ICT environment, Lent and Pinkowska (2012) defined soft skills as "an aggregation of all interpersonal and personal learnable abilities, which contribute to the higher efficiency of the execution of the human factor related processes of project management". The soft side definition issue is further detailed when approached by Bond et al. (2004). In a comprehensive research focused on relational skills and interactional patterns between more and less effective managers, the authors defined reputational effectiveness as "the degree to which a manager has been responsive to the needs and expectations of constituents".

Although the project manager plays a major role in most of the analyzed literature, Dezdar and Ainin (2011) shows that is necessary to build some skill-balanced project team as, in this case, different team individuals have different skills, and the sum of their skills delivers all the skills needed for the project success. The same team approach was applied by Li et al. (2010), but they found that the team competence is not equal to the sum of each personal competency, being the team competence bigger than the sum. Henderson (2004) has a similar approach but still focusing on the team project effect. He presents that a single project manager soft skill, named communication, could improve the team satisfaction and with that improves their productivity leading to a better project performance.

It is therefore possible to state soft skills as the abilities related to the non-technical aspects of the project. They are complementary to the technical aspects and have been pointed out as one important success factor for the project, once it is responsible for connecting people and for making it follow the right direction (CREASY; ANANTATMULA, 2013; JOSEPH; ERASMUS; MARNEWICK, 2014; TAGHAVI; TAGHAVI; TAGHAVI, 2013; YNG LING; MA, 2014). However, it is not entirely clear which characteristics compose the success package of soft skills, which is discussed in topic 4.2. 


\section{RESEARCH METHODS}

So as to acquire a broad knowledge about the project management soft side issue, this research first took into consideration the possible ways a literature review can be developed; the initial intention was to use the bibliometric analysis, content analysis and semantic analysis approaches (BOOTE; BEILE, 2005). Mainly, this kind of methodology is used not only to probe the existing literature and to identify relevant patterns, words, and authors of the particular field of research, but also to investigate the evolution of the publications stratified by journals and by year. The literature review can be put into practice both manually or in a computer-aided way, depending on the number of data considered for the analysis.

Decisions on which research method to apply are mainly taken based on the results from the databases, particularly the sample size to be reviewed. There are several research methods available for helping in a systematic literature review (CARVALHO; FLEURY; LOPES, 2013). The bibliometric and semantic approaches are particularly useful for large sample sizes since they focus on metrics based on the number of publications and on the metadata. Content analysis, on the other hand, focuses on in-depth review of the sample but allows analytical flexibility, which lies in recognizing the importance of language in human cognition (DURIAU; REGER; PFARRER, 2007), which fits the soft side research characteristics well.

\subsection{Sampling}

For this paper, an initial sample was elaborated using two databases, ISI Web of Science and Scopus, aiming to cross check their results and highlight the documents to be studied. The article search was performed in October, 2015. The following search string was used, and no restrictions but the type of documents (Articles) were considered: "project manag ${ }^{\star}$ " and ("soft $\mathrm{t}^{\star}$ approach" or "soft" skill”" or "soft" side $^{\star *}$ or "relational* skill”" or "soft and hard skill*" or "leader competenc $c^{\star}$ " or "team competenc $c^{\star}$ " or "communication competenc" or soft-approach or soft-skill* or soft-side ${ }^{\star}$ ). This first search resulted in twenty nine entries in the ISI Web of Science and seventy one entries in Scopus, which, after a cross check between the databases, resulted in the exclusion of twenty-two coincident papers and a final list of seventy-eight articles. 
The first exclusion criterion was based on the abstracts. All these papers had their abstracts read for identifying those that did not fit within the scope of the study, excluding them from the final list, which then had forty nine papers. It was not possible to access the full paper of five articles, and another two articles were in languages (Russian and Greek) the authors do not master, resulting in forty-two articles. After that, all the papers from the final list were read to identify the definitions contained and applications of the soft side of project management, to be used in the content analysis.

All the papers selected had been published from 1994 to 2015, in 57 different journals, and $49 \%$ of the papers had their publication concentrated in the last five years. Among the journals, the International Journal of Project Management is the one with most papers in the subject, accounting for ten papers, and the Journal of Project Management is the second one, accounting for five papers. One Hundred and Fifty-four authors were identified, and the three most prolific authors published three papers each in this research stream. The papers had been written in 33 countries, the United States being the leader with fourteen papers, followed by the United Kingdom with ten papers and Australia with seven papers.

This section considers the evolution of the publications over different aspects. Among all the documents analyzed, sixteen (38\%) of them focus on soft skills in Information and Communication Technology (ICT), thirteen (31\%) of them had a general approach on the soft side of project management, without focusing on a particular subject. One possible reason for this number of ICT-related documents is their origins and the relationship of this topic with project management. For instance, fourteen documents (17\%) are associated with the United States, and the ICT field represents $4 \%$ of the GDP of this country.

The data showed that many kinds of research approaches were already used regarding project management soft side issues, as identified in the literature researched, but with a concentration of Exploratory and Confirmatory Surveys in eighteen articles (43\%), nine articles of each kind. Other approaches with intensive use are conceptual articles with nine articles (21\%), and case studies with eight articles (21\%). 


\subsection{Data analysis}

The final sample was analyzed in depth, applying content analysis with special care devoted to the coding process, deployed into the following categories: communication, leadership, team relationship, conflict management, management of the organization, motivation, self-confidence, training, knowledge, decision-making, empathy, and requirements.

The data collected was treated according to the authors that wrote the articles, the year of publication, and the soft definitions proposed by the authors. The two first characteristics were gathered from the metadata of the databases used, as described in section 2.1. The third characteristic was collected by reading articles and information mining. This information allows different analyses of the data and grouping the corresponding clusters.

\section{RESULTS}

The main results are presented herein considering the key topics composing the soft side concept. Even being part of the results, the soft side concept was presented in section 2 .

\subsection{Key topics}

A keyword analysis was performed for an overview of the academic field using the TagCrowd software. The most cited words were: "project", "management", "skills", "competency" and "soft", as expected. There are some other words correlated with soft skills, such as "communication", "team" and "leadership"; other groups of words are related to the industry sector analyzed, "software" and "construction". There are also the words "success" and "performance" showing that one focus of the researches was the relation between soft skills and project performance. Other words are related with the act of teaching and learning soft skills, such as "training", "learning", "education" and "knowledge", coming from a research cluster focused on soft aspects for personnel preparation and qualification.

Considering the comprehensive study of the "soft" definitions shown previously, the numbers of skills and characteristics to describe "soft skills" are numerous. The different characteristics are summarized in Table 1, which demonstrates the relations between the skills and their citation frequency. For constructing Table 1, the works that clearly presented a list of soft characteristics were considered, resulting in twenty papers $(48 \%)$ to be analyzed. 
Table 1 - Soft key topics.

\begin{tabular}{|c|c|c|c|c|c|c|c|c|c|c|c|c|c|c|c|}
\hline \multirow[b]{2}{*}{ REFERENCE } & \multicolumn{15}{|c|}{ CORE THEMES } \\
\hline & 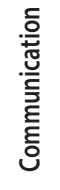 & 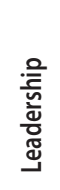 & $\underset{\stackrel{E}{\leftrightarrows}}{\stackrel{E}{\leftrightarrows}}$ & 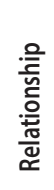 & 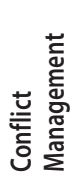 & 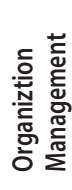 & . & 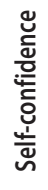 & 哭 & 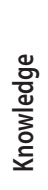 & 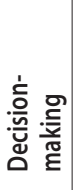 & $\begin{array}{l}\text { 촐 } \\
\text { 를 }\end{array}$ & 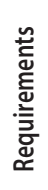 & 龸 & $\%$ \\
\hline Ahsan et al. (2012) & 1 & 1 & 1 & 1 & & & & & & & & & & 4 & $6 \%$ \\
\hline Andersen et al. (2006) & 1 & & & & & & & & & & & & & 1 & $2 \%$ \\
\hline Beukers (2011b) & 1 & 1 & & & & & 1 & & & & & & & 3 & $5 \%$ \\
\hline $\begin{array}{c}\text { Brones \& Carvalho } \\
\text { (2014) }\end{array}$ & & & & 1 & & & & & 1 & & & & & 2 & $3 \%$ \\
\hline $\begin{array}{l}\text { Carvalho \& Rabechini } \\
\text { Junior (2015) }\end{array}$ & 1 & & & 1 & 1 & & & & & & & & & 3 & $5 \%$ \\
\hline Fletcher et al. (2014) & 1 & 1 & 1 & 1 & 1 & & 1 & & 1 & & 1 & & & 8 & $13 \%$ \\
\hline $\begin{array}{l}\text { Karrbom Gustavsson \& } \\
\text { Hallin (2014b) }\end{array}$ & & 1 & & & & & & & & & & & & 1 & $2 \%$ \\
\hline Joseph et al. (2014) & 1 & & & & & & & & & & & & 1 & 2 & $3 \%$ \\
\hline Pant \& Baroudi (2008) & 1 & 1 & 1 & & & 1 & & & & & & & & 4 & $6 \%$ \\
\hline Parker et al. (2013) & 1 & 1 & & & 1 & & & & & & & & & 3 & $5 \%$ \\
\hline $\begin{array}{l}\text { Petter \& Randolph } \\
\text { (2012) }\end{array}$ & 1 & & 1 & & 1 & & & 1 & & 1 & & & & 5 & $8 \%$ \\
\hline $\begin{array}{c}\text { Stevenson \& } \\
\text { Starkweather (2010) }\end{array}$ & 1 & & & & & & & & & & & & & 1 & $2 \%$ \\
\hline Taghavi et al. (2013) & 1 & & & 1 & & & 1 & 1 & & & & & & 4 & $6 \%$ \\
\hline Toor \& Ofori (2008) & & 1 & & & & & & & & & & & & 1 & $2 \%$ \\
\hline $\begin{array}{c}\text { Vouzas \& Psychogios } \\
(2007)\end{array}$ & & & 1 & & & 1 & & & 1 & & & & & 3 & $5 \%$ \\
\hline $\begin{array}{l}\text { Vukčević \& Đurović } \\
\text { (2006) }\end{array}$ & & 1 & 1 & 1 & & & & & & & & & & 3 & $5 \%$ \\
\hline Wautelet \& Kop (2012) & 1 & & 1 & 1 & & & & & & 1 & & & & 4 & $6 \%$ \\
\hline Yng Ling \& Ma (2014) & 1 & & & & & & & & & & & & & 1 & $2 \%$ \\
\hline Zhang \& Fan (2013) & 1 & & 1 & & 1 & 1 & & 1 & & & & & & 5 & $8 \%$ \\
\hline Zhang et al. (2013) & 1 & 1 & 1 & & 1 & & & & & & & 1 & & 5 & $8 \%$ \\
\hline TOTAL & 15 & 9 & 9 & 7 & 6 & 3 & 3 & 3 & 3 & 2 & 1 & 1 & 1 & 63 & $100 \%$ \\
\hline$\%$ & $24 \%$ & $14 \%$ & $11 \%$ & $11 \%$ & $10 \%$ & $5 \%$ & $5 \%$ & $5 \%$ & $5 \%$ & $3 \%$ & $2 \%$ & $2 \%$ & $2 \%$ & $100 \%$ & \\
\hline
\end{tabular}

Source: Elaborated by the authors. 
The data from Table 1 enables us to state that the most frequent topics of project management soft side is communication, followed by leadership, and team.

As revealed by Table 1, communication was mentioned by fifteen of the researched sample of twenty articles. A more detailed analysis shows that this skill has already been among the subjects of many surveys focused on the importance of soft skills to a project success. For instance, taken as a dependent variable by Carvalho and Rabechini Junior (2015), the skill contributed to validating hypotheses regarding the importance of soft side for a project success. Importance that was also shown and even more emphasized by Fletcher, Gunning and Coates (2014), as communication showed to be one of the most prevalent factors influencing project outcomes. In Yng Ling and Ma (2014), the survey focused specifically on the importance of communication among project team members, also corroborating its significance to the project outcomes. The relationship between communication and project results was also the subject of surveys presented by Beukers (2011), Zhang, Zuo and Zillante (2013), Zhang and Fan (2013) and, Henderson (2008). Besides surveys focusing on projects outcomes, the skills were also part of the subjects in surveys on job requirements, as shown by Ahsan, Ho and Khan (2013) and, Lent and Pinkowska (2012).

Taken independently of other soft skills, communication competence was the subject of a specific research conducted by Henderson (2004). The focus was specifically on the two-core communication process, named encoding and decoding. With a comprehensive survey, the author researched the association of project managers' encoding and decoding with team members' satisfaction and productivity, with positive results. Besides, the work presents a literature review on the specific skill, providing relevant definitions and references on the subject.

Leadership is the second most cited soft characteristic. Interpersonal skills were the most important success factor for forming the product development collaborations and alliances (BEUKERS, 2011). Project managers must have a broad range of skills and abilities to ensure a successful outcome, keeping focus without authority (BEUKERS, 2011; KILKELLY, 2011). Confirming Makatsoris (2009), which says that soft skills are difficult to access using traditional academic means, leadership skills can be developed in students by encouraging them to participate in community development projects (EVANS, 1999 cited in TOOR; OFORI, 2008). Leadership is learned when people assume key roles in the organization and in teams (TOOR; OFORI, 2008).

Team formation is one of the most important characteristics of the soft side of project management, considering that it was the third most cited characteristic. It is necessary to build a skill-balanced project team having internal and external teams (DEZDAR; AININ, 2011). Team members interact with each other 
and create a combined competence that increases the quality of the project, more than the technical competencies (LI et al., 2010; VINOD; DHANALAKSHMI; SAHADEV, 2009; ZHANG; FAN, 2013). Because of these skills, companies have been looking for employees attaching importance to soft proficiencies and the abilities to transmit them (AHSAN; HO; KHAN, 2013; PANT; BAROUDI, 2008; PETTER; RANDOLPH, 2009).

Besides the most cited and critical project management soft issues, as shown in Table 1, some issues were considered relevant to detail due to their peculiarity or originality. Focused on "proposing an approach to develop a system for Research Project Leadership Stipulation", to be applied to academicians and possible researchers on advanced $\mathrm{R} \& \mathrm{D}$ benefited by funding programs, Taghavi, Taghavi and Taghavi (2013) not only showed that the level of an academic leadership expertise alone does not determine the success of R\&D project success, but that soft skills are of greater importance. Due to the difficulty inherent to measuring soft behavioral skills, their work was measured by applying indirect metrics to evaluate, for example, the academics' self-confidence and motivation.

The definition of reputational effectiveness by Bond et al. (2004) was the argument used by another relevant work. Having in mind that strong connections across functions are critical for new product development and with strict attention to managers' inclination to foster effective cross-functional relationships, Bond et al. (2004) aimed to compare the more and the less reputational effective managers, achieving conclusions regarding role-taking ability and openness (information sharing).

A specific and possibly unprecedented project management soft issue was addressed by Buckle and Thomas (2003). Based on portions of the Project Management Body of Knowledge, the authors, as they declared, initiated a discussion about the roles played by gendered logic systems in project management practices. Concluding, "Neither masculine nor feminine ways of reasoning or behaving is inherently superior to the other" but they emphasized that both are of importance to professionals and should be developed by them. Aiming to open the issue for the research community, no following work dealing with the same soft issue was identified by our work.

\section{DISCUSSION}

Soft skills are related to the ability to work in a team (ZHANG; ZUO; ZILLANTE 2013) and the ability to control and to persuade members to work in the expected direction (KILKELLY, 2011). Hence, the most important topics are communication, leadership and team ability, as presented in Table 1. 
The firm relationship between soft skills and teamwork, as reported, can be perceivable not only by the most cited topics over the years but also by other characteristics when considering the issue over the years, as presented in Table 2. Relationship and Conflict Management (CARVALHO; RABECHINI JUNIOR, 2015) are also behavioral, and non-technical skills directly related to teamwork and to the task of carrying out the project.

However, using the same data to draw an evolution of the topics in recent years - Table 2 -, more recently, topics related to the individual other than the team are observed to have been more cited in the literature in the last ten years. Approaching the project success issue from the individual side appears to be an academic challenging issue for the upcoming research agenda (CARVALHO; RABECHINI JUNIOR, 2015; FLETCHER; GUNNING; COATES, 2014; JOSEPH; ERASMUS; MARNEWICK, 2014; YNG LING; MA, 2014).

Table 2 - Key Topics over the years.

\begin{tabular}{|c|c|c|c|c|c|c|c|c|c|c|c|c|c|c|c|c|c|}
\hline & \multicolumn{5}{|c|}{ 1st period } & & & \multicolumn{5}{|c|}{ 2nd period } & & & & & \\
\hline & ঃ্ণ & ڤ్రి & ڤั & ઠे & 음 & 롱 & $\%$ & స్ & $\tilde{\check{N}}$ & 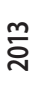 & $\stackrel{\nabla}{\stackrel{D}{*}}$ & $\stackrel{n}{\grave{c}}$ & 志 & $\%$ & 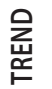 & 岕 & $\%$ \\
\hline Communication & 1 & & 1 & 1 & 1 & 4 & $24 \%$ & 1 & 1 & 5 & 3 & 1 & 11 & $27 \%$ & $\stackrel{\vdots}{\vdots}$ & 15 & $26 \%$ \\
\hline Leadership & 1 & & 2 & & & 3 & $18 \%$ & 1 & & 3 & 2 & & 6 & $15 \%$ & $\vdots$ & 9 & $16 \%$ \\
\hline Team & 1 & 1 & 1 & 1 & & 4 & $24 \%$ & & 1 & 3 & 1 & & 5 & $12 \%$ & $\vdots$ & 9 & $16 \%$ \\
\hline Relationship & 1 & & & & & 1 & $6 \%$ & & 1 & 2 & 2 & 1 & 6 & $15 \%$ & $\stackrel{\vdots}{\vdots}$ & 7 & $12 \%$ \\
\hline Conflict management & & & & 1 & & 1 & $6 \%$ & & & 3 & 1 & 1 & 5 & $12 \%$ & $\stackrel{a}{\vdots}$ & 6 & $10 \%$ \\
\hline $\begin{array}{l}\text { Organization } \\
\text { Management }\end{array}$ & & 1 & 1 & & & 2 & $12 \%$ & & & 1 & & & 1 & $2 \%$ & $\dot{\vdots}$ & 3 & $5 \%$ \\
\hline Motivation & & & & & & 0 & $0 \%$ & 1 & & 1 & 1 & & 3 & $7 \%$ & $\stackrel{\vdots}{\vdots}$ & 3 & $5 \%$ \\
\hline Self-confidence & & & & 1 & & 1 & $6 \%$ & & & 2 & & & 2 & $5 \%$ & $\vdots$ & 3 & $5 \%$ \\
\hline Training & & 1 & & & & 1 & $6 \%$ & & & & 1 & 1 & 2 & $5 \%$ & $\vdots$ & 3 & $5 \%$ \\
\hline & & & & & & 17 & $100 \%$ & & & & & & 41 & $100 \%$ & & 58 & $100 \%$ \\
\hline
\end{tabular}

Source: Elaborated by the authors. 
Moreover, a single article was identified proposing a way to measure soft behavioral skills (TAGHAVI; TAGHAVI; TAGHAVI, 2013).

This study has some limitations due to the methodological approach. The first limitation is the choice of only two databases. Nevertheless, they are some of the largest and most accredited reference databases; some articles could be outside our sample. The second limitation is the string used; although it is a vague string, maybe some articles related to soft skills in project management are outside the sample. Another limitation is that the expansion of the sample by a co-citation analysis was not performed, and could be a suggestion for future works, perhaps using a bibliometric approach.

\section{CONCLUSIONS}

This article contributes to the literature by surveying the soft side in the project management context. A total of forty-two articles from the ISI Web of Science and Scopus databases were analyzed.

This review shows a substantial prevalence of exploratory surveys, as $43 \%$ of the sample analyzed were found to apply this research method, according to the sampling data in section 2; this initial characteristic was taken as evidence of a call for a stronger research effort into the dichotomy between project management soft and hard sides.

Aspects related to the soft side were found to be treated by the literature when dealing with academic concerns and the preparation of future professionals (MAKATSORIS, 2009; POST; LEE, 2011; SOARES et al., 2013; STEVENSON; STARKWEATHER, 2010; TOOR; OFORI, 2008), when dealing with the importance devoted to the issue by organizational human resources staffs while conducting professional selection processes (AHSAN; HO; KHAN, 2013; LENT; PINKOWSKA, 2012), and when dealing with its importance to the projects success, the latter being identified as a recurrent topic (CREASY; ANANTATMULA, 2013; JOSEPH; ERASMUS; MARNEWICK, 2014; TAGHAVI; TAGHAVI; TAGHAVI, 2013; YNG LING; MA, 2014). In this case, the literature not only evaluated the soft side in an isolated manner but also took into consideration the hard side, so as to offer a conclusion on which characteristics are the most important. Most of them concluded that the soft side has more influence on the projects' success than the hard side, despite it still being controversial in the field (BEUKERS, 2011; CARVALHO; RABECHINI JUNIOR, 2015; HERAZO; LIZARRALDE; PAQUIN, 2012; FLETCHER; GUNNING; COATES, 2014; KILKELLY, 2011; YNG LING; MA, 2014). 
An analysis of the most frequent related topics on the soft side reveals that Communication, Leadership, and Team are the soft characteristics mostly dealt with and valued by the literature, as shown in Table 2 . Taken seriously into consideration by project teams, the three characteristics together act as facilitators of the projects success, due to the interaction between the team members, which creates a combined competence that increases the quality of the project, more than the technical competences (LI et al., 2010; VINOD; DHANALAKSHMI; SAHADEV, 2009; ZHANG; FAN, 2013). In conclusion, the three characteristics together act as the behavioral side of the professionals, which, aligned with Makatsoris (2009), which says that soft skills are hard to obtain through academic means, are mainly acquired during their professional years, complementing their technical side, acquired in their undergraduate years.

The soft side was also found to be treated in an isolated manner in the literature when dealing with specific issues. Some articles were classified as of relative importance because of their peculiarity or originality in dealing with indirect metrics to evaluate the soft skills as in Taghavi, Taghavi and Taghavi (2013), in dealing with the reputational effectiveness of managers as in Bond et al. (2004), and in discussing the roles played by gendered logic systems in project management practices as in Buckle and Thomas (2003).

This research has limitation due to the methodological choices, particularly related to the sample analyzed. The database choices, the search strings applied and topic analyzed have possible biases; hence, important articles can be missed in the process.

The future of the research into the field of soft skills is still open. This study points the following topics as trends for research into soft skills in the project management area: (a) the analysis of how soft skills and their balance with hard skills can affect project success (BEUKERS, 2011; CARVALHO; RABECHINI JUNIOR, 2015; HERAZO; LIZARRALDE; PAQUIN, 2012; FLETCHER; GUNNING; COATES, 2014; KILKELLY, 2011; ZHANG; FAN, 2013), (b) the stability of "Communication", "Leadership" and "Team work / relationship" as the most important soft skills (as shown in Table 2), (c) the focus of soft skills as a relevant aspect in the project manager's profile, including the academic formation as a way to increase the soft side emphasis among practioneers (AHSAN; HO; KHAN, 2013; CARVALHO; RABECHINI JUNIOR, 2015; FLETCHER; GUNNING; COATES, 2014; JOSEPH; ERASMUS; MARNEWICK, 2014; YNG LING; MA, 2014), and (d) the studies that thoroughly explore only one type of soft skills. 
The main challenges in this research area are: (a), new characteristics have been discussed as part of soft skill definition, especially personal ones, such as self-confidence, motivation, and training, (b) analyzing the relation between individual soft skills and success of the project is a difficult/complex issue, once combined soft skills are thought to be more powerful than individual ones, (c) the literature converges to a consensus definition of the main characteristics the soft side, since it involves different epistemological fields, and (d) the consolidation of the understanding of the balance of soft and hard skills in a project team towards project success.

\section{ACKNOWLEDGMENTS}

The authors would like to thank CNPq and FAPESP for supporting this research.

\section{REFERENCES}

AHLEMANN, F.; EL ARBI, F.; KAISER, M. G.; HECK, A. A process framework for theoretically grounded prescriptive research in the project management field. International Journal of Project Management, v. 31, n. 1, p. 43-56, 2013.

AHSAN, K.; HO, M.; KHAN, S. Recruiting project managers: A comparative analysis of competencies and recruitment signals from job advertisements. Project Management Journal, v. 44, n. 5, p. 36-54, 2013.

ALFAADEL, F.; ALAWAIRDHI, M.; AL-ZYOUD, M.; RAMZAN, M. An investigation to reveal why IT projects succeed or fail in Saudi Arabia. Life Science Journal, v. 11, n. 10, p. 146-154, 2014.

ANDERSEN, E. S.; BIRCHALL, D.; JESSEN, S. A.; MONEY, A. H. Exploring project success. Baltic Journal of Management, v. 1, n. 2, p. 127-147, 2006.

BEUKERS, M. W. Project management of life-science research projects: project characteristics, challenges and training needs. Drug Discovery Today, v. 16, n. 3-4, p. 93-98, 2011.

BOND, E. U.; WALKER, B. A.; HUTT, M. D.; REINGEN, P. H. Reputational Effectiveness in Cross-Functional Working Relationships. Journal of Product Innovation Management, v. 21, n. 1, p. 44-60, 2004. 
BOOTE, D. N.; BEILE, P. Scholars Before Researchers: On the Centrality of the Dissertation Literature Review in Research Preparation. Educational Researcher, v. 34, n. 6, p. 3-15, 2005.

BRONES, F.; CARVALHO, M. M. From 50 to 1: integrating literature toward a systemic ecodesign model. Journal of Cleaner Production, v. 96, p. 44-57, 2014.

BUCKLE, P.; THOMAS, J. Deconstructing project management: a gender analysis of project management guidelines. International Journal of Project Management, v. 21, n. 6, p. 433-441, 2003.

CARVALHO, M. M.; FLEURY, A.; LOPES, A. P. An overview of the literature on technology roadmapping (TRM): Contributions and trends. Technological Forecasting \& Social Change, v. 80, n. 7, p. 1418-1437, 2013.

CARVALHO, M. M.; RABECHINI JUNIOR, R. Impact of risk management on project performance: the importance of soft skills. International Journal of Production Research, v. 53, n. 2, p. 321-340, 2015.

CREASY, T.; ANANTATMULA, V. From Every Direction - How Personality Traits and Dimensions of Project Managers Can Conceptually Affect Project Success. Project Management Journal, v. 44, n. 6, p. 36-51, 2013.

DEZDAR, S.; AININ, S. Examining ERP implementation success from a project environment perspective. Business Process Management Journal, v. 17, n. 6, p. 919-939, 2011.

DURIAU, V. J.; REGER, R. K.; PFARRER, M. D. A Content Analysis of the Content Analysis Literature in Organization Studies Research Themes, Data Sources, and Methodological Refinements. Organizational Research Methods, v. 10, n. 1, p. 5-34, 2007.

EVANS, L. Managing to motivate: A guide for school leaders. London: Cassell, 1999.

FLETCHER, S. M.; GUNNING, J. G.; COATES, R. Soft skills of senior contracts managers in Northern Ireland. Proceedings of Institution of Civil Engineers: Management, Procurement and Law, v. 167, n. 1, p. 35-45, 2014.

GRABHER, G. Learning in projects,remembering in networks? Communality, sociality and connectivity in project ecologies. European Urban and Regional Studies, v. 11, n. 2, p. 103-123, 2004. 
HENDERSON, L. S. Encoding and decoding communication competencies in project management - an exploratory study. International Journal of Project Management, v. 22, n. 6, p. 469-476, 2004.

HENDERSON, L. S. The impact of project managers' communication competencies: Validation and extension of a research model for virtuality, satisfaction, and productivity on project teams. Project Management Journal, v. 39, n. 2, p. 48-59, 2008.

HERAZO, B.; LIZARRALDE, G.; PAQUIN, R. Sustainable development in the building sector; A Canadian case study on the alignment of strategic and tactical management. Project Management Journal, v. 43, n. 2, p. 84-100, 2012.

JOSEPH, N.; ERASMUS, W.; MARNEWICK, C. The Idle State of Information and Communication Technology Project Management. Journal of African Business, v. 15, n. 3, p. 184-196, 2014.

KARRBOM GUSTAVSSON, T.; HALLIN, A. Rethinking dichotomization: A critical perspective on the use of "hard" and "soft" in project management research. International Journal of Project Management, v. 32, n. 4, p. 568-577, 2014.

KILKELLY, E. Using training and development to recover failing projects. Human Resource Management International Digest, v. 19, n. 4, p. 3-6, 2011.

LENT, B.; PINKOWSKA, M. Soft skills needed in the ICT project management - classification and maturity level assessment. International Journal of Applied Systemic Studies, v. 4, n. 3, p. 168-185, 2012.

LI, Y.; CHANG, K. -C.; CHEN, H. -G.; JIANG, J. J. Software development team flexibility antecedents. Journal of Systems and Software, v. 83, n. 10, p. 1726-1734, 2010.

MAKATSORIS, C. An information and communication technologies-based framework for enhancing project management education through competence assessment and development. Human Factors and Ergonomics In Manufacturing, v. 19, n. 6, p. 544-567, 2009.

PANT, I.; BAROUDI, B. Project management education: The human skills imperative. International Journal of Project Management, v. 26, n. 2, p. 124-128, 2008 . 
PARKER, D.; CHARLTON, J.; RIBEIRO, A.; PATHAK, R. D. Integration of project-based management and change management: Intervention methodology. International Journal of Productivity and Performance Management, v. 62 , n. 5, p. 534-544, 2013.

PAROLIA, N.; JIANG, J. J.; KLEIN, G. The presence and development of competency in IT programs. Journal of Systems and Software, v. 86, n. 12, p. 31403150, 2013.

PETTER, S.; RANDOLPH, A. Developing soft skills to manage user expectations in IT projects: Knowledge reuse among IT project managers. Project Management Journal, v. 40, n. 4, p. 45-59, 2009.

PLANT, R.; WILLCOCKS, L. Critical Success Factors in International ERP Implementations : A Case Research Approach. Journal of Computer Information Systems, v. 47, n. 3, p. 60-70, 2007.

POST, M. A.; LEE, R. Lessons learned from the York University Rover Team (YURT) at the University Rover Challenge 2008-2009. Acta Astronautica, v. 68, n. 7-8, p. 1343-1352, 2011.

SHARMA, A.; GUPTA, A. Impact of organisational climate and demographics on project specific risks in context to Indian software industry. International Journal of Project Management, v. 30, n. 2, p. 176-187, 2012.

SHURVILLE, S.; WILLIAMS, J. Managing in-house development of a campus-wide information system. Campus-Wide Information Systems, v. 22, n. 1, p. 15-27, 2005.

SOARES, F. O.; SEPÚlVEDA, M. J.; MONTEIRO, S.; LIMA, R. M.; DINIS-CARVALHO, J. An integrated project of entrepreneurship and innovation in engineering education. Mechatronics, v. 23, n. 8, p. 987-996, 2013.

SÖDERLUND, J.; MAYLOR, H. Project management scholarship: Relevance, impact and five integrative challenges for business and management schools. International Journal of Project Management, v. 30, n. 6, p. 686-696, 2012.

STEVENSON, D. H.; STARKWEATHER, J. A. PM critical competency index: IT execs prefer soft skills. International Journal of Project Management, v. 28, n. 7, p. 663-671, 2010.

TAGHAVI, M.; TAGHAVI, H.; TAGHAVI, M. Research project leadership stipulation system. Campus-Wide Information Systems, v. 30, n. 4, p. 266-287, 2013. 
TOOR, S. -U. -R.; OFORI, G. Developing Construction Professionals of the 21st Century: Renewed Vision for Leadership. Journal of Professional Issues in Engineering Education and Practice, v. 134, n. 3, p. 279-286, 2008.

VINOD, V.; DHANALAKSHMI, J.; SAHADEV, S. Software Team Skills on Software Product Quality. Asian Journal of Information Technology, v. 8, n. 1, p. 8-13, 2009.

WALKER, D. H. T.; SHEN, Y. J. Project understanding, planning, flexibility of management action and construction time performance: two Australian case studies. Construction Management and Economics, v. 20, n. 1, p. 31-44, 2002.

WAUTELET, Y.; KOLP, M. e-SPM: An Online Software Project Management Game. International Journal of Engineering Education, v. 28, n. 6, p. 13161325, 2012.

YNG LING, F. Y.; MA, Y. Effect of competency and communication on project outcomes in cities in China. Habitat International, v. 44, p. 324-331, 2014.

ZHANG, F.; ZUO, J.; ZILLANTE, G. Identification and evaluation of the key social competencies for Chinese construction project managers. International Journal of Project Management, v. 31, n. 5, p. 748-759, 2013.

ZHANG, L.; FAN, W. Improving performance of construction projects: A project manager's emotional intelligence approach. Engineering, Construction and Architectural Management, v. 20, n. 2, p. 195-207, 2013. 